\title{
The photolysis module JVAL-14, compatible with the MESSy standard, and the JVal PreProcessor (JVPP)
}

\author{
R. Sander ${ }^{1}$, P. Jöckel ${ }^{2}$, O. Kirner ${ }^{3}$, A. T. Kunert ${ }^{1}{ }^{*}$, J. Landgraf $^{4}$, and A. Pozzer ${ }^{1}$ \\ ${ }^{1}$ Air Chemistry Department, Max-Planck Institute of Chemistry, P.O. Box 3060, 55020 Mainz, Germany \\ ${ }^{2}$ Deutsches Zentrum für Luft- und Raumfahrt (DLR), Institut für Physik der Atmosphäre, Oberpfaffenhofen, \\ 82230 Wessling, Germany \\ ${ }^{3}$ Steinbuch Centre for Computing, Karlsruhe Institute of Technology, P.O. Box 3640, 76021 Karlsruhe, Germany \\ ${ }^{4}$ Netherlands Institute for Space Research (SRON), Utrecht, the Netherlands \\ *now at: Multiphase Chemistry Department, Max-Planck Institute of Chemistry, P.O. Box 3060, 55020 Mainz, Germany
}

Correspondence to: R. Sander (rolf.sander@mpic.de)

Received: 17 March 2014 - Published in Geosci. Model Dev. Discuss.: 24 April 2014

Revised: 28 September 2014 - Accepted: 7 October 2014 - Published: 13 November 2014

\begin{abstract}
We present version 14 of the photolysis module JVAL. Taking atmospheric conditions as input, JVAL calculates photolysis rate coefficients, i.e. the speed of dissociation of atmospheric molecules in the sunlight. Computational efficiency is obtained through the use of parameters for polynomial curve fitting and lookup tables. Physical changes compared to the previous version include a parameterization of the Lyman-alpha absorption, and an update of the UV/VIS cross sections to the most recent recommended values. JVAL also includes the auxiliary program JVPP (JVal PreProcessor) which pre-calculates these parameters based on the absorption cross sections and quantum yields of the atmospheric molecules. It is possible to use JVAL either as a stand-alone program or as a module inside the Modular Earth Submodel System (MESSy). JVAL is a community model published under the GNU General Public License.
\end{abstract}

\section{Introduction}

Many important chemical reactions in the atmosphere are photolysis reactions where molecules dissociate in the sunlight. The rate coefficients of these reactions are called $J$ values. They depend on the actual atmospheric shortwave radiation field and are therefore not constant in time, but have to be reevaluated with changing solar zenith angle, temperature, ozone concentrations, clouds, aerosols, and other atmospheric properties. Landgraf and Crutzen (1998) presented an efficient method for online calculations of $J$ values which has been used in several atmospheric models, e.g. MATCH (von Kuhlmann et al., 2003) and ECHAM5/MESSy (Jöckel et al., 2006, 2010). For the implementation into the latter, the photolysis code was adapted to the Modular Earth Submodel System (MESSy) interface by Jöckel et al. (2005) and called JVAL. Since the efficiency of JVAL results from a parameterization, it is necessary to recalculate the parameters whenever a new chemical species is added or new spectral data become available. Although straightforward, this has been a tedious procedure, resulting in a time lag between publication of the latest spectral information and its implementation into JVAL. To automate the generation of these parameters, the JVal PreProcessor (JVPP) has been written. Here we present the new version JVAL-14, which also includes JVPP.

\section{JVAL model description}

\subsection{Original code}

This section provides a brief summary of the parameterization method used in JVAL. For full details, the reader is referred to the original paper by Landgraf and Crutzen (1998).

The $J$ value for a molecule $\mathrm{X}\left(J_{\mathrm{X}}\right)$ can be calculated via the integral

$J_{X}=\int_{\lambda_{\min }}^{\lambda_{\max }} \sigma_{\mathrm{X}}(\lambda) \varphi_{\mathrm{X}}(\lambda) F(\lambda) \mathrm{d} \lambda$, 
Table 1. Subdivision of the spectral range into eight bands. $\lambda_{\text {ini }}$ and $\lambda_{\text {fin }}$ are the initial and final wavelength.

\begin{tabular}{clcc}
\hline Band & Name & $\lambda_{\text {ini }}[\mathrm{nm}]$ & $\lambda_{\text {fin }}[\mathrm{nm}]$ \\
\hline 1 & Schumann-Runge & 178.6 & 202.0 \\
2 & Herzberg & 202.0 & 241.0 \\
3 & Hartley & 241.0 & 289.9 \\
4 & & 289.9 & 305.5 \\
5 & UV-B & 305.5 & 313.5 \\
6 & & 313.5 & 337.5 \\
7 & UV-A & 337.5 & 422.5 \\
8 & Chappuis & 422.5 & 682.5 \\
\hline
\end{tabular}

where $\lambda$ is the wavelength, $\sigma_{\mathrm{X}}$ the absorption cross section, $\varphi_{\mathrm{X}}$ the quantum yield, and $F(\lambda)$ the spectral actinic flux. The photochemically active spectral interval considered here is $\lambda_{\min }=178 \mathrm{~nm} \leq \lambda \leq 683 \mathrm{~nm}=\lambda_{\max }$. Numerically, this integral can be approximated as the sum

$J_{\mathrm{X}} \approx \sum_{i=1}^{N} \sigma_{\mathrm{X}}\left(\lambda_{i}\right) \varphi_{\mathrm{X}}\left(\lambda_{i}\right) F\left(\lambda_{i}\right) \Delta \lambda_{i}$,

where the spectrum is divided into $N$ wavelength bins. Here, $\sigma_{\mathrm{X}}\left(\lambda_{i}\right), \varphi_{\mathrm{X}}\left(\lambda_{i}\right)$, and $F\left(\lambda_{i}\right)$ are average values in the bins of size $\Delta \lambda_{i}$. However, to obtain accurate results, $N$ has to be large, leading to excessive computing times. As an alternative, Landgraf and Crutzen (1998) suggested a method using only the eight spectral bands shown in Table 1 . The basic idea is to calculate the $J$ value not with a fine spectral resolution but with only a few spectral bands in which Eq. (1) is approximated by:

$J_{\mathrm{X}} \approx \sum_{i=1}^{8} J_{i, \mathrm{X}}^{\mathrm{a}} \times \delta_{i}$,

where $J_{i, \mathrm{X}}^{\mathrm{a}}$ is the $J$ value for a purely absorbing atmosphere and $\delta_{i}$ describes the influence of scattering by air molecules, aerosols, and cloud particles. The $J_{i, \mathrm{X}}^{\mathrm{a}}$ are precalculated with a fine spectral resolution and are approximated during runtime from lookup tables or polynomial fits. The lookup calculations are performed for a purely absorbing atmosphere using the Lambert-Beer law. For the online calculations, the two-stream method PIFM (Practical Improved Flux Method, Zdunkowski et al., 1980) is employed. The advantage of this procedure is that the fine absorption structures that are present in $\sigma_{\mathrm{X}}$ and $\varphi_{\mathrm{X}}$ in integral (1) are considered. Only Rayleigh and cloud scattering, included in $F\left(\lambda_{i}\right)$, are treated with a coarse spectral resolution.

$J_{i, \mathrm{X}}^{\mathrm{a}}$ is calculated as a function of the slant overhead column of ozone. For the Schumann-Runge and for the Herzberg band (bands 1 and 2 in Table 1), the dependence on the corresponding slant $\mathrm{O}_{2}$ column is considered as well.

The effect of aerosols and clouds on the photodissociation rates is governed by the actinic flux calculation at reference wavelengths of the spectral bands. Because of the spectrally smooth optical properties of aerosols and clouds in the UV and visible part of the spectrum, this approach is appropriate to account for the enhanced scattering of light by clouds and aerosols. The main bottleneck of the scheme represents the radiative transfer solver, which in the presented approach is a two-stream solver. Landgraf and Crutzen (1998) showed that errors in the order of 10-20\% could be introduced in the presence of clouds and aerosols. Due to the two-stream model, aerosols and clouds are characterized by three optical parameters: the absorption and scattering optical depths, and the asymmetry factor of the scattering phase function. Thus, in principle any aerosol submodel providing these three parameters can be used, which is just a matter of interfacing between the aerosol submodel and JVAL. In the current version of JVAL, optical properties of the aerosols are taken from lookup tables for relative humidities of $0,50,70,80,90$, 95, and $98 \%$ by Shettle and Fenn (1979). Extinction coefficients (variable aext in the code), absorption coefficients (aabs), and asymmetry parameters (ag) were interpolated to the eight wavelength bands. Scattering is calculated as the difference between aext and aabs. For clouds, the single scatter albedo $\widetilde{\omega}_{i}(\mathrm{wC})$ is calculated using data from Table 1 from Slingo (1989) for the range 250-690 nm.

\subsection{Physical changes}

The following physical changes have been implemented into the code since the publication of Landgraf and Crutzen (1998):

- in the planetary boundary layer (PBL), a mixture of rural and maritime aerosol is used, depending on the surface type. A sea-land fraction (slf) between 0 and 1 is used as input for JVAL. Above the PBL, free tropospheric aerosol is considered.

- For the solar Lyman-alpha line, a parameterization based on the reduction factor method from Chabrillat and Kockarts $(1997,1998)$ is used. For oxygen, $R_{\mathrm{O}_{2}}$ (r_o2) is defined. For a few other molecules $\left(\mathrm{CO}_{2}\right.$, $\mathrm{CH}_{4}, \mathrm{SF}_{6}, \mathrm{H}_{2} \mathrm{SO}_{4}$, and $\mathrm{H}_{2} \mathrm{O}$ ), the dimensionless factor $R_{\mathrm{M}}$ (r_m) is used.

- In the original code by Landgraf and Crutzen (1998), the spherical geometry of the atmosphere was taken into account by employing the air mass factor correction of Kasten and Young (1989). In the current code, the correction factors $F_{\text {corr }}\left(f j \_c o r r\right)$ from Lamago et al. (2003) are used. Further improvements are planned for the future: see Sect. 5 .

- Using JVPP, all photochemical reactions in JVAL have been updated. If available, we adopted the recommended UV/VIS cross sections from Sander et al. (2011b). Otherwise, we used the most recent measurements, as shown in Table 2. Data files for the cross sec- 
tions were obtained from the UV/VIS Spectral Atlas by Keller-Rudek et al. (2013).

\subsection{Technical changes}

The following technical changes have been implemented into the code since the publication of Landgraf and Crutzen (1998):

- the syntax was converted from FORTRAN77 to Fortran90.

- In the past, different and incompatible ASCII input files were used for different versions of the code. Now, these molecule-specific parameters are generated with JVPP and included in the Fortran90 code.

- The code was modularized according to the MESSy standard. Briefly, this allows exactly the same code to be used for calculating $J$ values in the CAABA/MECCA box model (Sander et al., 2011a), the global ECHAM5/MESSy Atmospheric Chemistry (EMAC) model (Jöckel et al., 2010), the COSMO/MESSy limited area model (Kerkweg and Jöckel, 2012), or any other base model that is MESSycompatible. For details, see Jöckel et al. (2005).

- A standardized interface via a Fortran90 namelist couples the JVAL module to the base model. This namelist (CPL) comprises switches to select which calculations are to be performed and entries to specify required input data (i.e. the channel objects, see Jöckel et al., 2010) for ozone, the cosine of the solar zenith angle, the distance between Earth and Sun (in AU, astronomical units), and the solar activity. An additional ozone climatology is required, which is used above the model top layer. More details on the namelists are documented in Sect. 2.3 of the "JVAL and JVPP User Manual", which is part of the Supplement.

\section{JVPP model description}

As described above, JVAL uses parameters in lookup tables and polynomial fits to calculate the values of $J_{i, \mathrm{X}}^{\mathrm{a}}$ from Eq. (3). To provide these parameters, JVPP has been written. JVPP works in three steps for each molecule X.

First, it reads a data file with absorption cross sections $\sigma_{\mathrm{X}}$ in the UV/visible range at an arbitrary spectral resolution and converts (interpolates) them to a fixed grid of 176 wavelengths. The default method is a linear interpolation between the points of the original spectrum which conserves the integrated value. Alternatively, a variety of spline-based interpolation methods can be chosen. For molecules where quantum yields $\varphi_{\mathrm{X}}$ and/or the temperature dependence of the cross sections $\sigma_{\mathrm{X}}(T)$ are available, those are interpolated as well.
As an example, the spectrum of $\mathrm{OClO}$ is shown in Fig. 1 before and after interpolation. Detailed plots for all molecules are available in the Supplement.

In the second step, a range of typical atmospheric conditions is scanned to obtain effective values for all eight bands of the spectral range (Table 1). Slant overhead ozone columns of up to 7000 Dobson units are used. For bands 1 and 2 (178 to $241 \mathrm{~nm}$ ), the concentration of oxygen is also varied. For molecules with temperature-dependent cross sections, $T$ is varied in the range from 180 to $320 \mathrm{~K}$. The results are stored in temporary files.

Finally, in the last step, the precalculated values are used to obtain polynomial fits which allow the $J$ values to be calculated as a function of temperature, ozone, and oxygen. The fitting parameters are then written into a Fortran90 include file which can be used by JVAL.

Table 2 shows all photolysis reactions that are currently included in JVPP, as well as the references for the UV/VIS spectra used. More information about the JVPP code can be found in the user manual, which is in the manual / directory of the JVAL code in the Supplement.

\section{Model evaluation and applications}

Thanks to the MESSy structure, the JVAL photolysis submodel can easily be incorporated into different models. To evaluate the new code, we used a simple column model, an atmospheric chemistry box model, and a global 3dimensional general circulation model.

\subsection{The simple JVAL column model for testing}

The JVAL column model, which is included in the Supplement, can be used for simple tests. As input, the following properties of an atmospheric air column must be defined: temperature, pressure, humidity, ozone concentration, and cloud cover. In addition, a set of solar zenith angles and the surface albedo must be defined. The output contains $J$ values for all specified zenith angles and all altitudes of the column. Detailed information on how to run the column model can be found in the user manual, which is in the manual / directory of the JVAL code in the Supplement.

\subsection{The CAABA box model}

The new JVAL submodel has been implemented in the CAABA box model as described by Sander et al. (2011a). Since version 3.3, CAABA uses the updated absorption cross sections as listed in Table 2. 

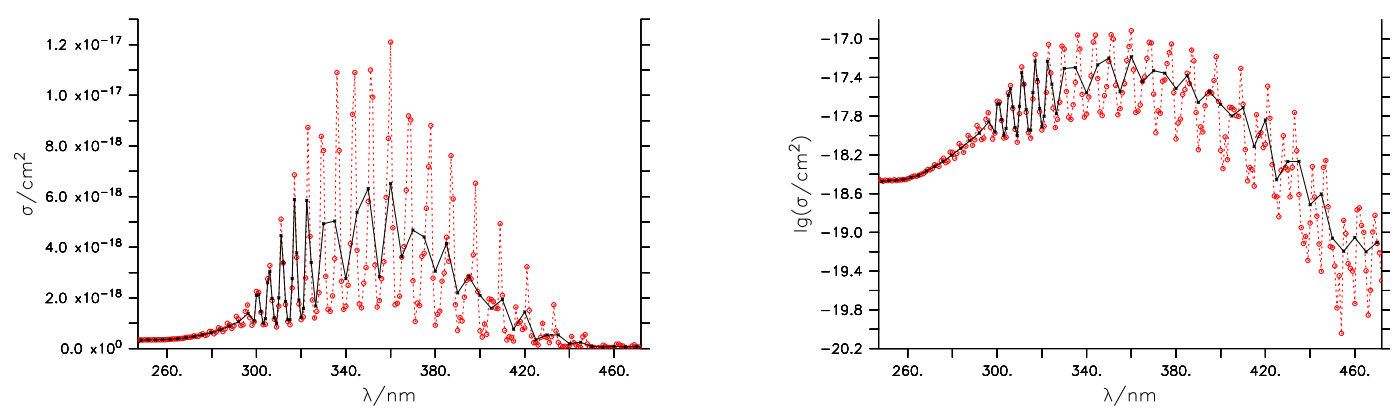

Figure 1. Absorption cross sections of $\mathrm{OClO}$ on a linear (left) and logarithmic (right) scale. The red line shows the original data taken from Sander et al. (2011b); the black line shows data after interpolation by JVPP to a fixed grid of 176 wavelengths.

\subsection{The global EMAC model: $J$ values and atmospheric implications}

JVAL has also been implemented in the latest EMAC-2.50 model, which is based on version 2.50 of MESSy ${ }^{1}$.

Global fields of $J$ values from the old and the new code are compared for all photolysis reactions. As an example, the results for ozone are shown in Figs. 2 and 3. Detailed plots for all molecules are available in the Supplement.

To test the atmospheric implications of the updated $J$ values, two model simulations have been performed using the updated and the old $J$ values, respectively. The simulations have been carried out in T42L90MA resolution, i.e. with a triangular truncation at wave number 42 of the spectral ECHAM5 core, which corresponds to an approximate $2.8^{\circ} \times$ $2.8^{\circ}$ quadratic Gaussian grid. The vertical model setup comprised 90 layers from the surface up to $0.01 \mathrm{hPa}(\approx 80 \mathrm{~km})$ in the middle atmosphere (MA). The model time step was 600 s. A Newtonian relaxation technique ("nudging") of the prognostic variables temperature, vorticity, divergence, and the logarithm of the surface pressure towards ERA-Interim reanalysis data from ECMWF (Dee et al., 2011) has been applied, in order to nudge the model dynamics towards the observed meteorology. The nudging has been applied above the boundary layer up to approximately $10 \mathrm{hPa}$. From the comprehensive MECCA atmospheric chemistry (Sander et al., 2011a), a mechanism for the troposphere, the stratosphere, and the lower mesosphere was selected, similarly to Jöckel et al. (2010). It includes ozone-related chemistry of the troposphere and non-methane hydrocarbons (NMHCs) up to isoprene. The chemical mechanism consists of 145 gas phase species and 298 reactions. The aqueous phase chemistry and wet deposition were calculated by the submodel SCAV (Tost et al., 2006), dry deposition by the submodel DDEP (formerly DRYDEP, Kerkweg et al., 2006a), and the prescribed emissions and boundary conditions have been handled by the submodels OFFEMIS (formerly OFFLEM) and TNUDGE (Kerkweg et al., 2006b). Isoprene emissions from plants and $\mathrm{NO}$ emissions from soil have been calculated on-

\footnotetext{
${ }^{1}$ http://www.messy-interface.org
}

line with the submodel ONEMIS (formerly ONLEM, Kerkweg et al., 2006b), NO from lightning with the submodel LNOX (for the present simulations with the parameterization of Grewe et al., 2001), and air-sea gas exchange of isoprene, DMS, and methanol with the submodel AIRSEA (Pozzer et al., 2006). Boundary conditions for greenhouse gases and anthropogenic emissions have been used according to the definition of the REF-C1SD simulation of the IGAC/SPARC Chemistry Climate Model Initiative (CCMI1) project $^{2}$ (Eyring et al., 2013). For the reference simulation $^{3}$ spanning the years 1979 to 2012 , the updated $J$ values have been used.

From this reference simulation, a sensitivity simulation with the old $J$ values was branched in January 2000. After 5 years of simulation (August 2005), the differences between the atmospheric compositions (old vs. updated) were already in a dynamical steady state without showing continuously diverging trends. We analyse the differences between the simulations exemplarily for the monthly averages of January and July 2005 , respectively. Because of relatively small changes between the old and the new $J$ values, the differences of $\mathrm{O}_{3}$ and related substances are in general limited and do not show a clear pattern. In Fig. 4, we show absolute and relative differences between the two simulations for $\mathrm{O}_{3}$. The relative differences are well below $10 \%$ through the entire atmosphere. For $\mathrm{CF}_{2} \mathrm{ClBr}$ (Halon 1211), $\mathrm{CF}_{3} \mathrm{Br}$ (Halon 1301), and $\mathrm{CH}_{3} \mathrm{Br}$, the cross section update from DeMore et al. (1997) to Sander et al. (2011b) leads to higher $J$ values of these substances in the troposphere and thus to higher $\mathrm{BrO}$ values in this region, as shown in Fig. 5. Detailed comparison plots for a large number of atmospherically relevant species are available in the Supplement.

\footnotetext{
${ }^{2}$ http://www.met.reading.ac.uk/ccmi/

${ }^{3}$ RC1SD-base-01 within the ESCiMo project, see http://www. pa.op.dlr.de/ PatrickJoeckel/ESCiMo/.
} 
Table 2. JVAL photolysis reactions.

\begin{tabular}{|c|c|c|}
\hline \# & Reaction & Reference for spectrum and comments \\
\hline $\mathrm{J} 1000$ & $\mathrm{O}_{2} \stackrel{\mathrm{h} v}{\rightarrow} \mathrm{O}+\mathrm{O}$ & $\begin{array}{l}\text { Sander et al. (2011b), } \\
\text { Lyman-alpha from Chabrillat and Kockarts (1997) and } \\
\text { Chabrillat and Kockarts (1998), Schumann-Runge band parameteriza- } \\
\text { tion from Koppers and Murtagh (1996) }\end{array}$ \\
\hline $\mathrm{J} 1001 \mathrm{~b}$ & $\mathrm{O}_{3} \stackrel{\mathrm{h} v}{\rightarrow} \mathrm{O}\left({ }^{3} \mathrm{P}\right)+\mathrm{O}_{2}$ & Sander et al. (2011b) \\
\hline J1001a & $\mathrm{O}_{3} \stackrel{\mathrm{h} v}{\rightarrow} \mathrm{O}\left({ }^{1} \mathrm{D}\right)+\mathrm{O}_{2}$ & Sander et al. (2011b) \\
\hline $\mathrm{J} 2101$ & $\mathrm{H}_{2} \mathrm{O}_{2} \stackrel{\mathrm{h} v}{\rightarrow} \mathrm{OH}+\mathrm{OH}$ & Sander et al. (2011b) \\
\hline J3101 & $\mathrm{NO}_{2} \stackrel{\mathrm{h} v}{\rightarrow} \mathrm{NO}+\mathrm{O}$ & Sander et al. (2011b) \\
\hline J3103a & $\mathrm{NO}_{3} \stackrel{\mathrm{h} v}{\rightarrow} \mathrm{NO}_{2}+\mathrm{O}$ & Sander et al. (2011b) \\
\hline J3103b & $\mathrm{NO}_{3} \stackrel{\mathrm{h} \nu}{\rightarrow} \mathrm{NO}+\mathrm{O}_{2}$ & Sander et al. (2011b) \\
\hline J3104 & $\mathrm{N}_{2} \mathrm{O}_{5} \stackrel{\mathrm{h} v}{\rightarrow} \mathrm{NO}_{2}+\mathrm{NO}_{3}$ & Sander et al. (2011b) \\
\hline J3201 & $\mathrm{HNO}_{3} \stackrel{\mathrm{h} v}{\rightarrow}$ products & Sander et al. (2011b) \\
\hline J3202 & $\mathrm{HNO}_{4} \stackrel{\mathrm{h} v}{\rightarrow}$ products & Sander et al. (2011b), IR overtones from Roehl et al. (2002) \\
\hline J4204 & $\mathrm{PAN} \stackrel{\mathrm{h} v}{\rightarrow}$ products & Sander et al. (2011b) \\
\hline J3200 & $\mathrm{HONO} \stackrel{\mathrm{h} v}{\rightarrow}$ products & Sander et al. (2011b) \\
\hline J4100 & $\mathrm{CH}_{3} \mathrm{OOH} \stackrel{\mathrm{h} v}{\rightarrow}$ products & Sander et al. (2011b) \\
\hline J4101a & $\mathrm{HCHO} \stackrel{\mathrm{h} v}{\rightarrow} \mathrm{CO}+\mathrm{H}_{2}$ & Sander et al. (2011b),quantum yields at $300 \mathrm{~K}$ and $1 \mathrm{~atm}$ \\
\hline $\mathrm{J} 4101 \mathrm{~b}$ & $\mathrm{HCHO} \stackrel{\mathrm{h} v}{\rightarrow} \mathrm{CHO}+\mathrm{H}$ & Sander et al. (2011b),quantum yields at $300 \mathrm{~K}$ and $1 \mathrm{~atm}$ \\
\hline J4202 & $\mathrm{CH}_{3} \mathrm{CO}_{3} \mathrm{H} \stackrel{\mathrm{h} \nu}{\rightarrow}$ products & Sander et al. (2011b) \\
\hline J4201 & $\mathrm{CH}_{3} \mathrm{CHO} \stackrel{\mathrm{h} v}{\rightarrow} \mathrm{CH}_{3}+\mathrm{CHO}$ & Sander et al. (2011b) \\
\hline J4301 & $\mathrm{CH}_{3} \mathrm{COCH}_{3} \stackrel{\mathrm{h} v}{\rightarrow}$ products & Hardcoded from old JVAL code.Pressure dependent. \\
\hline $\mathrm{J} 4303$ & MGLYOX $\stackrel{\mathrm{h} v}{\rightarrow}$ products & Hardcoded from old JVAL code.Pressure dependent. \\
\hline J6201 & $\mathrm{HOCl} \stackrel{\mathrm{h} v}{\rightarrow} \mathrm{OH}+\mathrm{Cl}$ & Sander et al. (2011b) \\
\hline J6101 & $\mathrm{OClO} \stackrel{\mathrm{h} v}{\rightarrow}$ products & Sander et al. (2011b), value at $204 \mathrm{~K}$ \\
\hline J6100 & $\mathrm{Cl}_{2} \mathrm{O}_{2} \underset{\mathrm{h} v}{\rightarrow} \mathrm{Cl}+\mathrm{ClO}_{2}$ & Sander et al. (2011b) \\
\hline J6301a & $\mathrm{ClNO}_{3} \stackrel{\mathrm{h} v}{\rightarrow} \mathrm{Cl}+\mathrm{NO}_{3}$ & Sander et al. (2011b) \\
\hline J6300 & $\mathrm{ClNO}_{2} \stackrel{\mathrm{h} v}{\rightarrow}$ products & Ghosh et al. (2012) \\
\hline J6000 & $\mathrm{Cl}_{2} \stackrel{\mathrm{h} v}{\rightarrow} 2 \mathrm{Cl}$ & Sander et al. (2011b) \\
\hline $\mathrm{J} 7100$ & $\mathrm{BrO} \stackrel{\mathrm{h} v}{\rightarrow} \mathrm{Br}+\mathrm{O}$ & Sander et al. (2011b) \\
\hline J7200 & $\mathrm{HOBr} \stackrel{\mathrm{h} v}{\rightarrow} \mathrm{OH}+\mathrm{Br}$ & Sander et al. (2011b) \\
\hline $\mathrm{J} 7600$ & $\mathrm{BrCl} \stackrel{\mathrm{h} v}{\rightarrow} \mathrm{Br}+\mathrm{Cl}$ & Sander et al. (2011b), based on formula by Maric et al. (1994) \\
\hline J7301 & $\mathrm{BrNO}_{3} \underset{\mathrm{h} v}{\rightarrow}$ products & Sander et al. (2011b) \\
\hline $\mathrm{J} 7300$ & $\mathrm{BrNO}_{2} \stackrel{\mathrm{h} v}{\rightarrow}$ products & Sander et al. (2011b) \\
\hline $\mathrm{J} 7000$ & $\mathrm{Br}_{2} \stackrel{\mathrm{h} \nu}{\rightarrow}$ products & Sander et al. (2011b) \\
\hline J6401 & $\mathrm{CCl}_{4} \stackrel{\mathrm{h} v}{\rightarrow}$ products & Sander et al. (2011b) \\
\hline J6400 & $\mathrm{CH}_{3} \mathrm{Cl} \stackrel{\mathrm{h} v}{\rightarrow}$ products & Sander et al. (2011b) \\
\hline J6402 & $\mathrm{CH}_{3} \mathrm{CCl}_{3} \stackrel{\mathrm{h} v}{\rightarrow}$ products & Sander et al. (2011b) \\
\hline $\mathrm{J} 6500$ & $\mathrm{CFCl}_{3} \stackrel{\mathrm{h} v}{\rightarrow}$ products & $\begin{array}{l}\text { Sander et al. (2011b), formula for temperature dependence from } \\
\text { DeMore et al. (1997) }\end{array}$ \\
\hline J6501 & $\mathrm{CF}_{2} \mathrm{Cl}_{2} \stackrel{\mathrm{h} v}{\rightarrow}$ products & $\begin{array}{l}\text { Sander et al. (2011b), formula for temperature dependence from } \\
\text { DeMore et al. (1997) }\end{array}$ \\
\hline $\mathrm{J} 7400$ & $\mathrm{CH}_{3} \mathrm{Br} \stackrel{\mathrm{h} v}{\rightarrow}$ products & Sander et al. (2011b) \\
\hline
\end{tabular}


Table 2. Continued.

\begin{tabular}{|c|c|c|}
\hline \# & Reaction & Reference for spectrum and comments \\
\hline J7601 & $\mathrm{CF}_{2} \mathrm{ClBr} \stackrel{\mathrm{h} v}{\rightarrow}$ products & Sander et al. (2011b) \\
\hline $\mathrm{J} 7500$ & $\mathrm{CF}_{3} \mathrm{Br} \stackrel{\mathrm{h} v}{\rightarrow}$ products & Sander et al. (2011b) \\
\hline J8401 & $\mathrm{CH}_{3} \mathrm{I} \stackrel{\mathrm{h} v}{\rightarrow}$ products & $\begin{array}{l}\text { Sander et al. (2011b), using data at } 298 \mathrm{~K} \text {, temperature dependence not } \\
\text { considered }\end{array}$ \\
\hline $\mathrm{J} 8402$ & $\mathrm{C}_{3} \mathrm{H}_{7} \mathrm{I} \stackrel{\mathrm{h} v}{\rightarrow}$ products & Sander et al. (2011b) \\
\hline J8403 & $\mathrm{CH}_{2} \mathrm{ClI} \stackrel{\mathrm{h} v}{\rightarrow}$ products & $\begin{array}{l}\text { Sander et al. (2011b), using data for } 298 \mathrm{~K} \text {, temperature dependence not } \\
\text { considered }\end{array}$ \\
\hline J8400 & $\mathrm{CH}_{2} \mathrm{I}_{2} \stackrel{\mathrm{h} v}{\rightarrow}$ products & $\begin{array}{l}\text { Sander et al. (2011b), using data for } 298 \mathrm{~K} \text {, temperature dependence not } \\
\text { considered }\end{array}$ \\
\hline J8100 & $\mathrm{IO} \stackrel{\mathrm{h} v}{\rightarrow} \mathrm{I}+\mathrm{O}$ & Sander et al. (2011b) \\
\hline J8200 & $\mathrm{HOI} \stackrel{\mathrm{h} v}{\rightarrow}$ products & Sander et al. (2011b) \\
\hline $\mathrm{J} 8000$ & $\mathrm{I}_{2} \stackrel{\mathrm{h} v}{\rightarrow} 2 \mathrm{I}$ & Keller-Rudek et al. (2013), based on Sander et al. (2006) \\
\hline J8600 & $\mathrm{ICl} \stackrel{\mathrm{h} \nu}{\rightarrow}$ products & $\begin{array}{l}\text { Sander et al. ( } 2011 \mathrm{~b} \text { ), values shown as " }<1 \text { " in their Table } 4 \mathrm{H}-10 \text { were } \\
\text { set to } 0\end{array}$ \\
\hline J8700 & $\mathrm{IBr} \stackrel{\mathrm{h} v}{\rightarrow}$ products & Sander et al. (2011b) \\
\hline $\mathrm{J} 8300$ & $\mathrm{INO}_{2} \stackrel{\mathrm{h} v}{\rightarrow}$ products & Sander et al. (2011b) \\
\hline \multirow[t]{3}{*}{ J8301 } & $\mathrm{INO}_{3} \stackrel{\mathrm{h} v}{\rightarrow}$ products & Sander et al. (2011b) \\
\hline & $\mathrm{SO}_{2} \stackrel{\mathrm{h} v}{\rightarrow} \mathrm{SO}_{2}^{*}$ & Danielache et al. (2008), quantum yield for dissociation is unknown. \\
\hline & $\mathrm{SO}_{3} \stackrel{\mathrm{h} v}{\rightarrow}$ products & Sander et al. (2011b) \\
\hline J9000 & OCS $\stackrel{\mathrm{h} v}{\rightarrow}$ products & Sander et al. (2011b) \\
\hline $\mathrm{J} 2100$ & $\mathrm{H}_{2} \mathrm{O} \stackrel{\mathrm{h} v}{\rightarrow} \mathrm{H}+\mathrm{OH}$ & Sander et al. (2011b) \\
\hline $\mathrm{J} 3100$ & $\mathrm{~N}_{2} \mathrm{O} \stackrel{\mathrm{h} v}{\rightarrow} \mathrm{N}_{2}+\mathrm{O}\left({ }^{1} \mathrm{D}\right)$ & Sander et al. (2011b) \\
\hline J3102 & $\mathrm{NO} \stackrel{\mathrm{h} v}{\rightarrow} \mathrm{N}+\mathrm{O}$ & Hardcoded from old JVAL code. \\
\hline J4102 & $\mathrm{CO}_{2} \stackrel{\mathrm{h} v}{\rightarrow} \mathrm{CO}+\mathrm{O}$ & Shemansky (1972), Lyman-alpha from Inn et al. (1953) \\
\hline J6200 & $\mathrm{HCl} \stackrel{\mathrm{h} v}{\rightarrow} \mathrm{H}+\mathrm{Cl}$ & Sander et al. (2011b) \\
\hline $\mathrm{J} 7603$ & $\mathrm{CHCl}_{2} \mathrm{Br} \stackrel{\mathrm{h} v}{\rightarrow}$ products & Sander et al. (2011b) \\
\hline $\mathrm{J} 7604$ & $\mathrm{CHClBr}_{2} \stackrel{\text { hv }}{\rightarrow}$ products & Sander et al. (2011b) \\
\hline J7602 & $\mathrm{CH}_{2} \mathrm{ClBr} \stackrel{\mathrm{h} v}{\rightarrow}$ products & Sander et al. (2011b) \\
\hline J7401 & $\mathrm{CH}_{2} \mathrm{Br}_{2} \stackrel{\mathrm{h} v}{\rightarrow}$ products & Sander et al. (2011b) \\
\hline $\mathrm{J} 7402$ & $\mathrm{CHBr}_{3} \stackrel{\mathrm{h} v}{\rightarrow}$ products & $\begin{array}{l}\text { Sander et al. ( } 2011 \mathrm{~b} \text { ), formula for temperature dependence used not only } \\
\text { for } 290-340 \mathrm{~nm} \text { but also for }>340 \mathrm{~nm} \text {. }\end{array}$ \\
\hline J9002 & $\mathrm{SF}_{6} \stackrel{\mathrm{h} v}{\rightarrow}$ products & Lyman-alpha from Ravishankara et al. (1993) \\
\hline $\mathrm{J} 6301 \mathrm{~b}$ & $\mathrm{ClNO}_{3} \stackrel{\mathrm{h} v}{\rightarrow} \mathrm{ClO}+\mathrm{NO}_{2}$ & Sander et al. (2011b) \\
\hline J4411 & MACR $\stackrel{\mathrm{h} v}{\rightarrow}$ products & Hardcoded from old JVAL code.Pressure dependent. \\
\hline J4401 & $\mathrm{MVK} \stackrel{\mathrm{h} v}{\rightarrow}$ products & Hardcoded from old JVAL code.Pressure dependent. \\
\hline J4208 & $\mathrm{CHOCHO} \stackrel{\mathrm{h} v}{\rightarrow} 2 \mathrm{CHO}$ & Hardcoded from old JVAL code.Pressure dependent. \\
\hline $\mathrm{J} 4205$ & $\mathrm{HOCH}_{2} \mathrm{CHO} \stackrel{\mathrm{h} v}{\rightarrow}$ products & Sander et al. (2011b) \\
\hline \multirow[t]{2}{*}{ J4103 } & $\mathrm{CH}_{4} \stackrel{\mathrm{h} v}{\rightarrow}$ products & Lyman-alpha from Fig. 1 of Turco (1975) \\
\hline & $\mathrm{H}_{2} \mathrm{SO}_{4} \stackrel{\mathrm{h} v}{\rightarrow} \mathrm{SO}_{3}+\mathrm{H}_{2} \mathrm{O}$ & Hardcoded from old JVAL code. \\
\hline
\end{tabular}



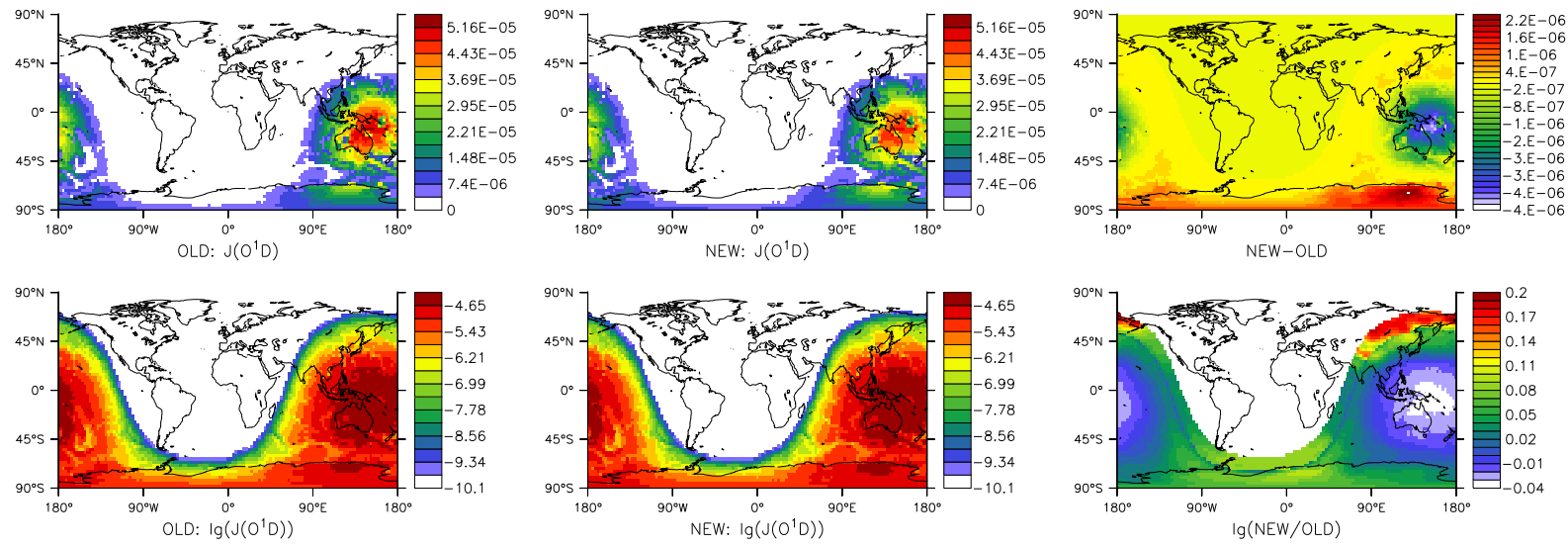

Figure 2. Comparison of old and new $J$ values (in s ${ }^{-1}$ ) for $\mathrm{O}_{3} \rightarrow \mathrm{O}\left({ }^{1} \mathrm{D}\right)$, calculated for 1 January 2000, 02:00 UTC at the surface. The first row is plotted on a linear scale, the second on a logarithmic scale. The left column shows the old result, the centre column the new result, and the right column the differences.

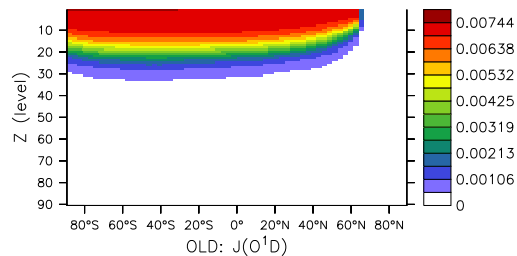

OLD: J(O'D)

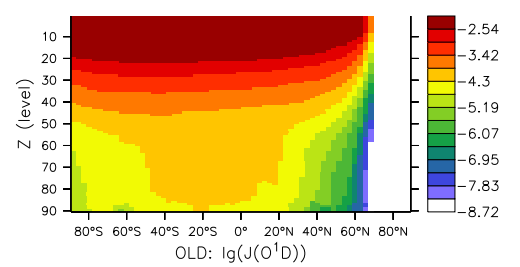

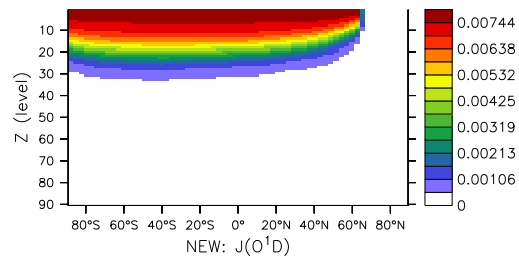
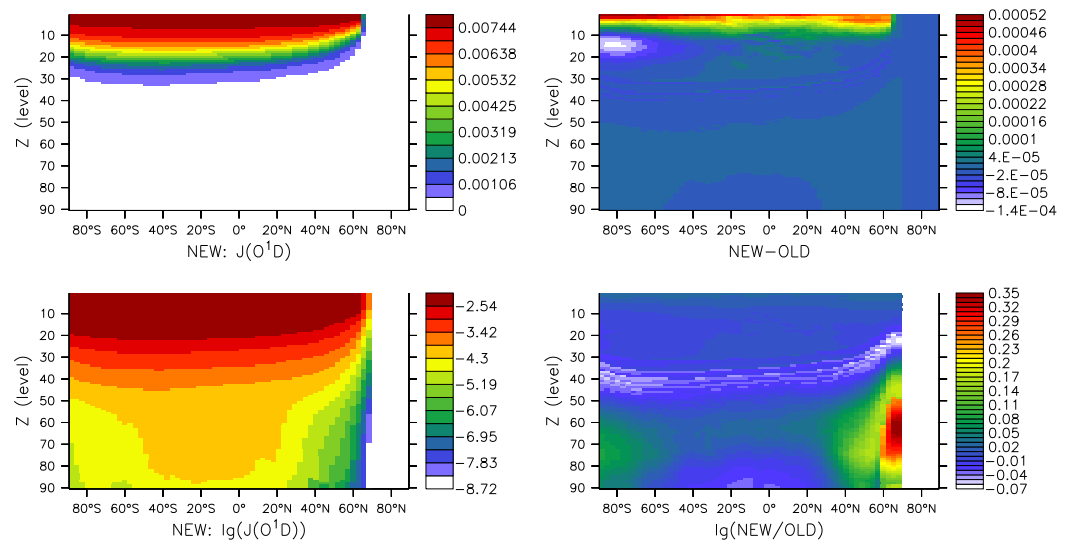

Figure 3. Comparison of the vertical profiles of the old and new $J$ values (in s ${ }^{-1}$ ) for $\mathrm{O}_{3} \rightarrow \mathrm{O}\left({ }^{1} \mathrm{D}\right)$, calculated for $1 \mathrm{January} 2000,02: 00 \mathrm{UTC}$ at a longitude of $138^{\circ} \mathrm{E}$ and 90 model levels (up to $0.01 \mathrm{hPa}$ ). The first row is plotted on a linear scale, the second on a logarithmic scale. The left column shows the old result, the centre column the new result, and the right column the differences.

\section{Summary and outlook}

We have presented the current version of the photolysis module JVAL and JVPP. Both are community models published under the GNU General Public License ${ }^{4}$. The model code and a user manual can be found in the Supplement. Regarding model development, our future plans include to:

- simulate photochemistry under twilight conditions. An extension of the current JVAL module based on Williams et al. (2006) is under development. Using Eq. (2) to infer $J$ values, the actinic fluxes are calculated by a pseudo-spherical radiative transfer solver. Here, the direct solar beam is calculated in spherical geometry but the transport of the diffuse radiation fields is described for a plan parallel model atmosphere. Currently,

\footnotetext{
${ }^{4}$ http://www.gnu.org/copyleft/gpl.html
}

this JVAL extension is being verified with full-spherical reference simulations.

- Improve the aerosol coupling: it is desirable to implement a generalized coupling (via channel objects, see Jöckel et al., 2010) to the required aerosol properties (extinction coefficient, absorption coefficient, and asymmetry parameter). This will enable not only the usage of alternative, offline prescribed aerosol climatologies as replacement for the implemented climatology, but also a direct, consistent coupling to the aerosol properties calculated online, if an aerosol submodel is running.

- Compare $J$ values generated by JVAL with those generated by other photolysis models, e.g. Fast-JX ${ }^{5}$ or TUV ${ }^{6}$.

\footnotetext{
${ }^{5}$ http://www.ess.uci.edu/researchgrp/prather/scholar_software/ fast-jx

${ }^{6} \mathrm{http}: / / \mathrm{cprm}$. acd.ucar.edu/Models/TUV
} 

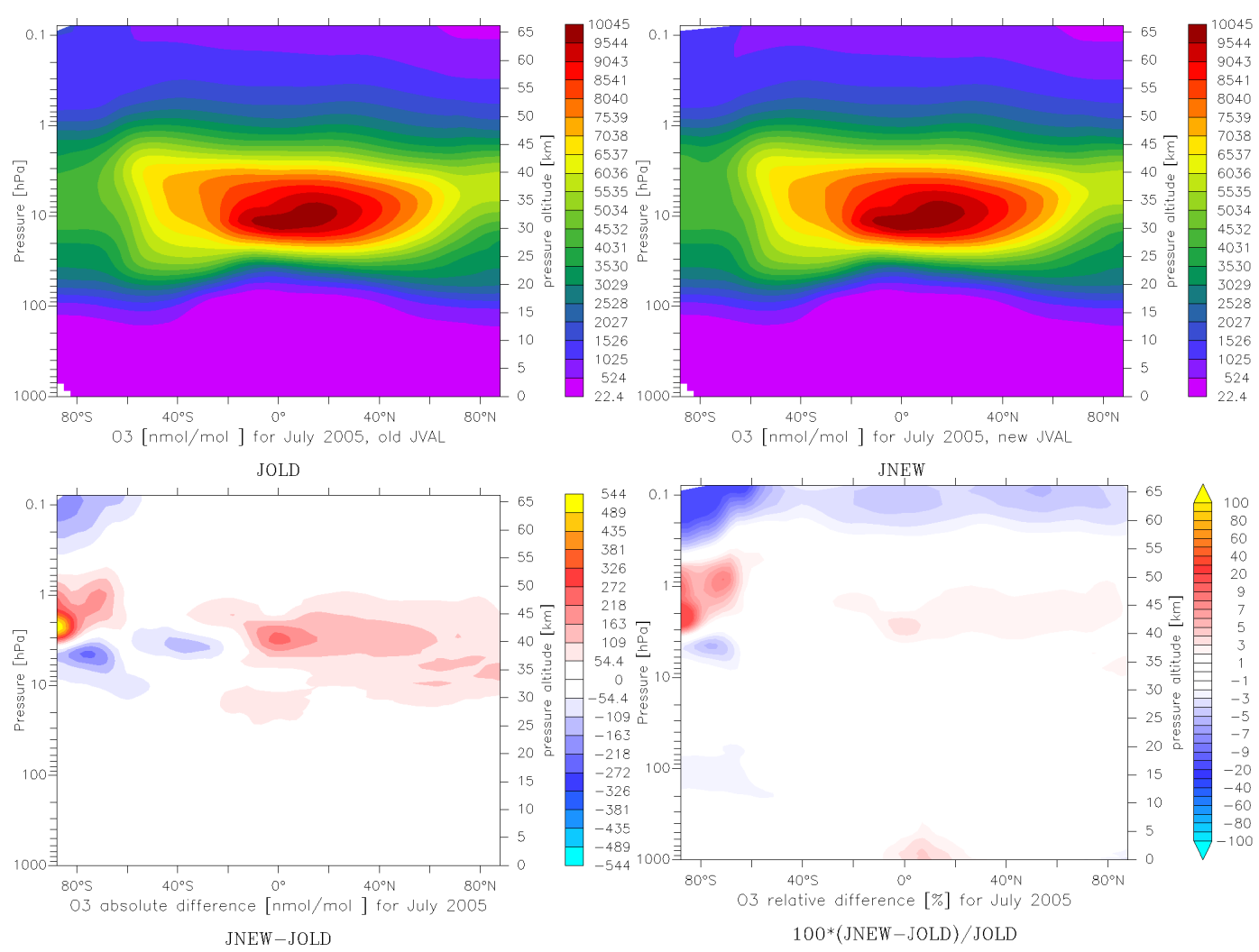

Figure 4. Effect of updated $J$ values on ozone. All plots refer to zonally averaged monthly mean values of July 2005 .
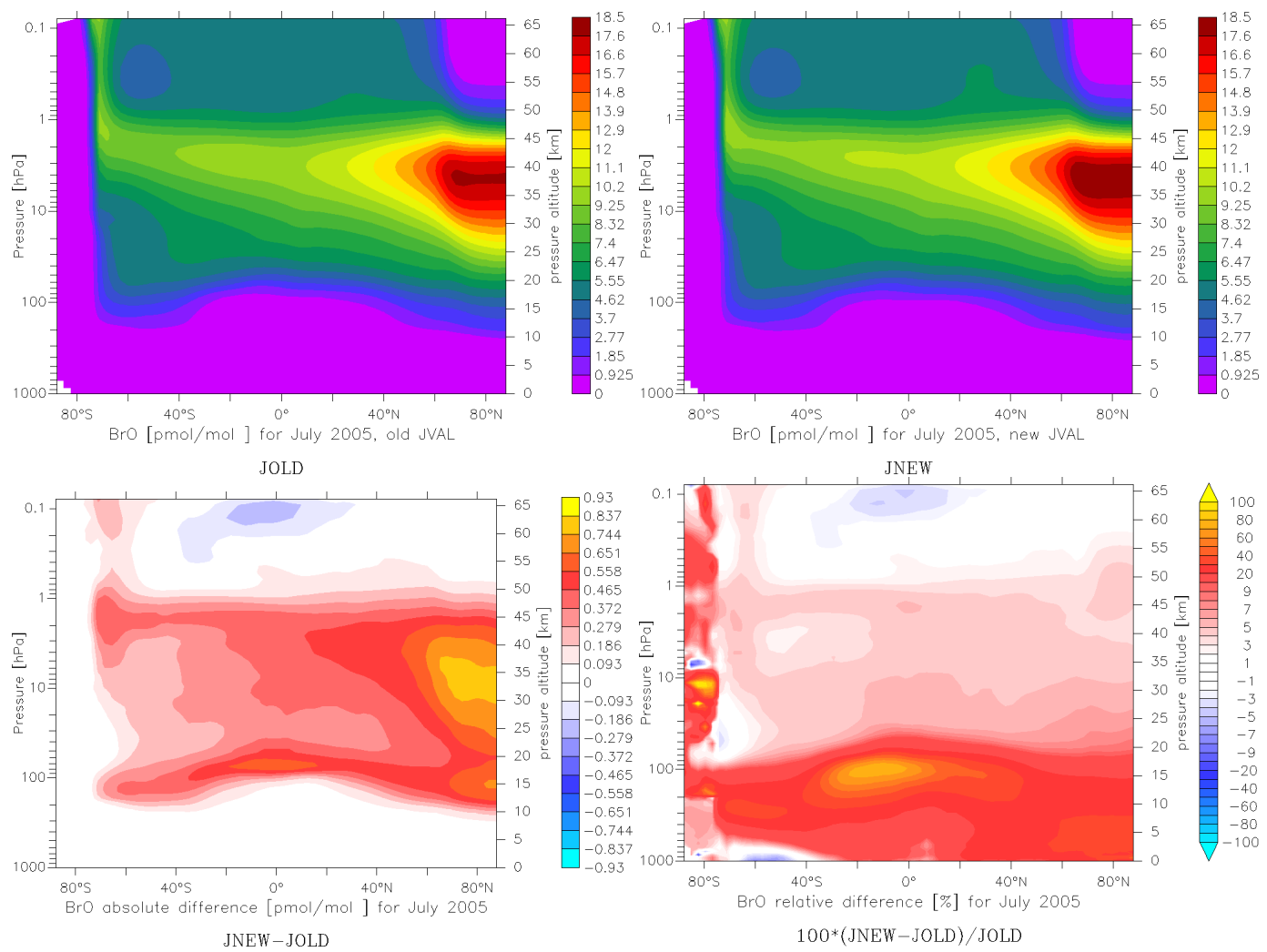

Figure 5. Effect of updated $J$ values on BrO. All plots refer to zonally averaged monthly mean values of July 2005 . 
Several additional plots, the model code for JVAL and JVPP, and a user manual are available online as a Supplement.

\section{The Supplement related to this article is available online at doi:10.5194/gmd-7-2653-2014-supplement.}

Author contributions. R. Sander wrote the JVPP code. J. Landgraf wrote the original code on which JVAL is based. P. Jöckel and R. Sander integrated JVAL into the MESSy modelling system. A. Kunert compared the $J$ values to those before the spectra were updated. P. Jöckel, O. Kirner, and A. Pozzer performed global simulations and evaluated the atmospheric implications.

Acknowledgements. We would like to thank R. von Glasow, A. Kerkweg, M. Kunze, and R. Ruhnke for help with the code and beta-testing. We also wish to acknowledge the use of the Ferret program from NOAA's Pacific Marine Environmental Laboratory (http://ferret.pmel.noaa.gov) for creating graphics in this paper.

The service charges for this open access publication have been covered by the Max Planck Society.

Edited by: A. Stenke

\section{References}

Chabrillat, S. and Kockarts, G.: Simple parameterization of the absorption of the solar Lyman-alpha line, Geophys. Res. Lett., 24, 2659-2662, 1997.

Chabrillat, S. and Kockarts, G.: Correction to "Simple parameterization of the absorption of the solar Lyman-alpha line", Geophys. Res. Lett., 25, 79, 1998.

Danielache, S. O., Eskebjerg, C., Johnson, M. S., Ueno, Y., and Yoshida, N.: High-precision spectroscopy of ${ }^{32} \mathrm{~S},{ }^{33} \mathrm{~S}$, and ${ }^{34} \mathrm{~S}$ sulfur dioxide: Ultraviolet absorption cross sections and isotope effects, J. Geophys. Res., 113, D17314, doi:10.1029/2007JD009695, 2008.

Dee, D. P., Uppala, S. M., Simmons, A. J., Berrisford, P., Poli, P., Kobayashi, S., Andrae, U., Balmaseda, M. A., Balsamo, G., Bauer, P., Bechtold, P., Beljaars, A. C. M., van de Berg, L., Bidlot, J., Bormann, N., Delsol, C., Dragani, R., Fuentes, M., Geer, A. J., Haimberger, L., Healy, S. B., Hersbach, H., Hólm, E. V., Isaksen, L., Kållberg, P., Köhler, M., Matricardi, M., McNally, A. P., Monge-Sanz, B. M., Morcrette, J.-J., Park, B.-K., Peubey, C., de Rosnay, P., Tavolato, C., Thépaut, J.-N., and Vitart, F.: The ERA-Interim reanalysis: configuration and performance of the data assimilation system, Q. J. Roy. Meteor. Soc., 137, 553-597, 2011.

DeMore, W. B., Sander, S. P., Golden, D. M., Hampson, R. F., Kurylo, M. J., Howard, C. J., Ravishankara, A. R., Kolb, C. E., and Molina, M. J.: Chemical kinetics and photochemical data for use in stratospheric modeling. Evaluation number 12, JPL Publication 97-4, Jet Propulsion Laboratory, Pasadena, CA, 1997.
Eyring, V., Lamarque, J.-F., Hess, P., Arfeuille, F., Bowman, K., Chipperfield, M. P., Duncan, B., Fiore, A. M., Gettelman, A., Giorgetta, M., Granier, C., Hegglin, M., Kinnison, D., Kunze, M., Langematz, U., Luo, B., Martin, R., Matthes, K., Newman, P. A., Peter, T., Robock, A., Ryerson, A., Saiz-Lopez, A., Salawitch, R., Schultz, M., Shepherd, T. G., Shindell, D. T., Stähelin, J., Tegtmeier, S., Thomason, L. W., Tilmes, S., Vernier, J.P., Waugh, D. W., and Young, P. J.: Overview of IGAC/SPARC chemistry-climate model initiative (CCMI) community simulations in support of upcoming ozone and climate assessments, http://elib.dlr.de/84929/ (last access: 12 November 2014), 2013.

Ghosh, B., Papanastasiou, D. K., Talukdar, R. K., Roberts, J. M., and Burkholder, J. B.: Nitryl chloride $\left(\mathrm{ClNO}_{2}\right)$ : UV/Vis absorption spectrum between 210 and $296 \mathrm{~K}$ and $\mathrm{O}\left({ }^{3} \mathrm{P}\right)$ quantum yield at 193 and $248 \mathrm{~nm}$, J. Phys. Chem. A, 116, 5796-5805, 2012.

Grewe, V., Brunner, D., Dameris, M., Grenfell, J. L., Hein, R., Shindell, D., and Staehelin, J.: Origin and variability of upper tropospheric nitrogen oxides and ozone at northern mid-latitudes, Atmos. Environ., 35, 3421-3433, 2001.

Inn, E. C. Y., Watanabe, K., and Zelikoff, M.: Absorption coefficients of gases in the vacuum ultraviolet. Part III. $\mathrm{CO}_{2}$, J. Chem. Phys., 21, 1648-1650, 1953.

Jöckel, P., Sander, R., Kerkweg, A., Tost, H., and Lelieveld, J.: Technical Note: The Modular Earth Submodel System (MESSy) - a new approach towards Earth System Modeling, Atmos. Chem. Phys., 5, 433-444, doi:10.5194/acp-5-433-2005, 2005.

Jöckel, P., Tost, H., Pozzer, A., Brühl, C., Buchholz, J., Ganzeveld, L., Hoor, P., Kerkweg, A., Lawrence, M. G., Sander, R., Steil, B., Stiller, G., Tanarhte, M., Taraborrelli, D., van Aardenne, J., and Lelieveld, J.: The atmospheric chemistry general circulation model ECHAM5/MESSy1: consistent simulation of ozone from the surface to the mesosphere, Atmos. Chem. Phys., 6, 5067-5104, doi:10.5194/acp-6-5067-2006, 2006.

Jöckel, P., Kerkweg, A., Pozzer, A., Sander, R., Tost, H., Riede, H., Baumgaertner, A., Gromov, S., and Kern, B.: Development cycle 2 of the Modular Earth Submodel System (MESSy2), Geosci. Model Dev., 3, 717-752, doi:10.5194/gmd-3-717-2010, 2010.

Kasten, F. and Young, A. T.: Revised optical air mass tables and approximation formula, Appl. Opt., 28, 4735-4738, 1989.

Keller-Rudek, H., Moortgat, G. K., Sander, R., and Sörensen, R.: The MPI-Mainz UV/VIS Spectral Atlas of Gaseous Molecules of Atmospheric Interest, Earth Syst. Sci. Data, 5, 365-373, doi:10.5194/essd-5-365-2013, 2013.

Kerkweg, A. and Jöckel, P.: The 1-way on-line coupled atmospheric chemistry model system MECO(n) - Part 1: Description of the limited-area atmospheric chemistry model COSMO/MESSy, Geosci. Model Dev., 5, 87-110, doi:10.5194/gmd-5-87-2012, 2012.

Kerkweg, A., Buchholz, J., Ganzeveld, L., Pozzer, A., Tost, H., and Jöckel, P.: Technical Note: An implementation of the dry removal processes DRY DEPosition and SEDImentation in the Modular Earth Submodel System (MESSy), Atmos. Chem. Phys., 6, 4617-4632, doi:10.5194/acp-6-4617-2006, 2006 a.

Kerkweg, A., Sander, R., Tost, H., and Jöckel, P.: Technical note: Implementation of prescribed (OFFLEM), calculated (ONLEM), and pseudo-emissions (TNUDGE) of chemical species in the Modular Earth Submodel System (MESSy), Atmos. Chem. Phys., 6, 3603-3609, doi:10.5194/acp-6-3603-2006, 2006 b. 
Koppers, G. A. A. and Murtagh, D. P.: Model studies of the influence of $\mathrm{O}_{2}$ photodissociation parameterizations in the Schumann-Runge bands on ozone related photolysis in the upper atmosphere, Ann. Geophys., 14, 68-79, doi:10.1007/s00585996-0068-9, 1996.

Lamago, D., Dameris, M., Schnadt, C., Eyring, V., and Brühl, C.: Impact of large solar zenith angles on lower stratospheric dynamical and chemical processes in a coupled chemistry-climate model, Atmos. Chem. Phys., 3, 1981-1990, doi:10.5194/acp-31981-2003, 2003.

Landgraf, J. and Crutzen, P. J.: An efficient method for online calculations of photolysis and heating rates, J. Atmos. Sci., 55, 863-878, 1998.

Maric, D., Burrows, J. P., and Moortgat, G. K.: A study of the UVvisible absorption spectra of $\mathrm{Br}_{2}$ and $\mathrm{BrCl}$, J. Photo. Photobio. A, 83, 179-192, 1994.

Pozzer, A., Jöckel, P., Sander, R., Williams, J., Ganzeveld, L., and Lelieveld, J.: Technical Note: The MESSy-submodel AIRSEA calculating the air-sea exchange of chemical species, Atmos. Chem. Phys., 6, 5435-5444, doi:10.5194/acp-6-5435-2006, 2006.

Ravishankara, A. R., Solomon, S., Turnipseed, A. A., and Warren, R. F.: Atmospheric lifetimes of long-lived halogenated species, Science, 259, 194-199, 1993.

Roehl, C. M., Nizkorodov, S. A., Zhang, H., Blake, G. A., and Wennberg, P. O.: Photodissociation of peroxynitric acid in the near-IR, J. Phys. Chem. A, 106, 3766-3772, 2002.

Sander, R., Baumgaertner, A., Gromov, S., Harder, H., Jöckel, P., Kerkweg, A., Kubistin, D., Regelin, E., Riede, H., Sandu, A., Taraborrelli, D., Tost, H., and Xie, Z.-Q.: The atmospheric chemistry box model CAABA/MECCA-3.0, Geosci. Model Dev., 4, 373-380, doi:10.5194/gmd-4-373-2011, $2011 \mathrm{a}$.

Sander, S. P., Friedl, R. R., Golden, D. M., Kurylo, M. J., Moortgat, G. K., Keller-Rudek, H., Wine, P. H., Ravishankara, A. R., Kolb, C. E., Molina, M. J., Finlayson-Pitts, B. J., Huie, R. E., and Orkin, V. L.: Chemical Kinetics and Photochemical Data for Use in Atmospheric Studies, Evaluation Number 15, JPL Publication 06-2, Jet Propulsion Laboratory, Pasadena, CA, http:// jpldataeval.jpl.nasa.gov (last access: 12 November 2014), 2006.
Sander, S. P., Abbatt, J., Barker, J. R., Burkholder, J. B., Friedl, R. R., Golden, D. M., Huie, R. E., Kolb, C. E., Kurylo, M. J., Moortgat, G. K., Orkin, V. L., and Wine, P. H.: Chemical Kinetics and Photochemical Data for Use in Atmospheric Studies, Evaluation No. 17, JPL Publication 10-6, Jet Propulsion Laboratory, Pasadena, http://jpldataeval.jpl.nasa.gov (last access: 12 November 2014), 2011b.

Shemansky, D. E.: $\mathrm{CO}_{2}$ extinction coefficient 1700-3000 A, J. Chem. Phys., 56, 1582-1587, 1972.

Shettle, E. P. and Fenn, R. W.: Models for the aerosols of the lower atmosphere and the effects of the humidity variations on their optical properties, Envronmental Research Papers, No. 676 AFGLTR-79-0114, Air Force Geophysics Laboratory, Hanscom AFB, Massachusetts 01731, 1979.

Slingo, A.: A GCM parameterization for the shortwave radiative properties of water clouds, J. Atmos. Sci., 46, 1419-1427, 1989.

Tost, H., Jöckel, P., Kerkweg, A., Sander, R., and Lelieveld, J.: Technical note: A new comprehensive SCAVenging submodel for global atmospheric chemistry modelling, Atmos. Chem. Phys., 6, 565-574, doi:10.5194/acp-6-565-2006, 2006.

Turco, R. P.: Photodissociation rates in the atmosphere below 100 km, Geophys. Surv., 2, 153-192, 1975.

von Kuhlmann, R., Lawrence, M. G., Crutzen, P. J., and Rasch, P. J.: A model for studies of tropospheric ozone and nonmethane hydrocarbons: Model description and ozone results, J. Geophys. Res., 108, 4294, doi:10.1029/2002JD002893, 2003.

Williams, J. E., Landgraf, J., Bregman, A., and Walter, H. H.: A modified band approach for the accurate calculation of online photolysis rates in stratospheric-tropospheric Chemical Transport Models, Atmos. Chem. Phys., 6, 4137-4161, doi:10.5194/acp-6-4137-2006, 2006.

Zdunkowski, W. G., Welch, R. M., and Korb, G.: An investigation of the structure of typical two-stream-methods for the calculation of solar fluxes and heating rates in clouds, Beitr. Phys. Atmos., 53, 147-166, 1980. 